\title{
TRACER STUDY PROGRAM STUDI PENDIDIKAN EKONOMI UNIVERSITAS NEGERI JAKARTA 2014
}

\author{
Darma Rika Swaramarinda \\ Fakultas Ekonomi, Universitas Negeri Jakarta \\ darmarika@gmail.com
}

\begin{abstract}
ABSTRACK
Improving the quality of graduates who can compete in the millenimum era is the responsibility of the world of education, especially the world of higher education in this case one of them is the State University of Jakarta .. One of the steps that can be done to prepare graduates who berkulaitas that is by adjusting the need for the competence of graduates with the world Work and industry. To know the suitability between graduate competence with user requirement is tracer study (trace study). This study was conducted with the aim to identify the competence of FE UNJ graduates in Economic Education Study Program based on the profile of waiting time, job suitability and first salary while working as well as company perception about alumni competence. This research is a qualitative study with the study population is alumni of Prodi Economic Education graduated from the period of 2011/2012. The sampling technique uses convenience sampling technique (non probability sampling). The data used in this study is the primary data obtained by interview or interview. The results obtained are about the suitability of the work field that is the teacher of $25 \%$ of the population
\end{abstract}

Key words: Tracer, Study, Economic Education 


\section{PENDAHULUAN}

Laporan tracer study memantau dan mengidentifikasi beberapa hal sebagai berikut:

- Daya saing lulusan yang ditunjukkan melalui waktu tunggu mendapatkan pekerjaan pertama, keberhasilan lulusan berkompetisi dalam seleksi dan gaji yang diperoleh.

- Relevansi (kesesuaian) pendidikan lulusan ditunjukkan melalui profil pekerjaan (macam dan tempat pekerjaan), relevansi pekerjaan dengan background pendidikan, manfaat mata kuliah yang diprogram dalam pekerjaan, saran lulusan untuk perbaikan kompetensi lulusan.

- Korelasi antara kegiatan ekstrakurikuler lulusan selama studi dan daya saing lulusan.

- Kendala dan hambatan yang dihadapi solusi yang diusulkan proses tracer study dan saran perbaikan proses dapat menjadi pertimbangan tim berikutnya.

- Persepsi alumni tentang layanan kemahasiswaan selama menjadi mahasiswa (mulai dari kegiatan MPA, beasiswa, kegiatan organisasi kemahasiswaan, lomba yang diikuti dan lannnya).

\section{Profile Pekerjaan Alumni Berdasarkan Program Studi} Menurut data yang kami peroleh berdasarkan program studi maka untuk program studi Pendidikan Ekonomi terdapat 20\% alumninya menjadi guru dan $78 \%$ alumninya menjadi karyawan, $1 \%$ yang melanjutkan kuliah dan $1 \%$ yang belum bekerja.

Profil Pekerjaan Alumni Per Program Studi

\begin{tabular}{cccccc}
\hline A & B & C & D & E & TOTAL \\
\hline 20 & 59 & - & - & 1 & 80 \\
\hline
\end{tabular}

Ket :

A : Guru

B : Karyawan

C : Wirausaha

D: Studi S1/S2

E : Belum Bekerja

Gambaran lebih rinci berkaitan dengan profile pekerjaan berdasarkan program studi di Fakultas Ekonomi adalah sebagai berikut yang disajikan dalam tabel profile pekerjaan.

\section{Profile pekerjaan Alumni} Prodi Pendidikan Ekonomi

\begin{tabular}{lc}
\hline \multicolumn{1}{c}{ POSISI } \\
\hline \multicolumn{1}{c}{ JENIS } & JUMLAH \\
\hline Guru & 20 \\
\hline Marketing & 3 \\
\hline Frontliner & 4 \\
\hline Call Center & 2 \\
\hline Teller & 7 \\
\hline Staff pengelola anggaran & 1 \\
\hline Konsultan & 1 \\
\hline Mikro Analyst & 1 \\
\hline Staff & 6 \\
\hline Karyawan Swasta & 1
\end{tabular}




\begin{tabular}{ll}
\cline { 2 - 2 } Customer Service & 4 \\
\hline Auditor & 1 \\
\hline General Affair & 3 \\
\hline Pembina & 1 \\
\hline Tim Kreatif & 1 \\
\hline Finance Cash Management & 1 \\
\hline Back Office & 1 \\
\hline Menganggur & 1 \\
\hline Supervisor & 1 \\
\hline Store Manager & 1 \\
\hline Sales and officer service & 1 \\
\hline Lalu Lintas Beasiswa & 1 \\
\hline Tata Usaha & 1 \\
\hline Klaim Support & 1 \\
\hline Staff Keuangan & 7 \\
\hline Pelayanan Masyarakat & 1 \\
\hline Sekretaris & 5 \\
\hline Data Entry & 1 \\
\hline Trainer & 1 \\
\hline & $\mathbf{8 0}$
\end{tabular}

3. Tingkat Gaji Pertama Alumni berdasarkan Program Studi

\begin{tabular}{lc}
\hline \multicolumn{1}{c}{ SKALA NOMINAL } & $\begin{array}{c}\text { PRODI } \\
\text { PEND. EKON }\end{array}$ \\
\hline < Rp. 1.000.000,- & 9 \\
\hline Rp. 1.000.000 - & \\
Rp. 2.000.000 & 50 \\
\hline Rp. 2.000.000 - & \\
Rp. 3.000.000 & 31 \\
\hline > Rp. 3.000.000,- & 4 \\
\hline TIDAK JAWAB & 6 \\
\hline TIDAK & \\
BERPENGHASILAN & - \\
\hline TOTAL & 100 \\
\hline
\end{tabular}

Berdasarkan tabel diatas profile gaji pertama yang diterima alumni jika dideskripsikan berdasarkan program studi dan diprosentasekan adalah sebagai berikut: untuk prodi Pendidikan Ekonomi yang gaji pertamanya dibawah satu juta $9 \%$, yang gajinya $1 \mathrm{~s} / \mathrm{d} 2$ juta $50 \%$, yang gajinya 2 s/d 3 juta sebanyak $31 \%$ dan yang gajinya diatas 3 juta sebanyak $4 \%$.

\begin{tabular}{|c|c|}
\hline \multicolumn{2}{|c|}{$\begin{array}{l}\text { 3. Profile lama menunggu } \\
\text { berdasarkan Program Studi }\end{array}$} \\
\hline JEDA WAKTU & $\begin{array}{c}\text { PRODI PEND. } \\
\text { EKON }\end{array}$ \\
\hline 1- 6 Bulan & 38 \\
\hline 7-12 Bulan & 1 \\
\hline$>1$ thn & - \\
\hline Tidak menunggu & 41 \\
\hline Kuliah & - \\
\hline Belum Bekerja & - \\
\hline TOTAL & 81 \\
\hline
\end{tabular}

Berdasarkan tabel diatas maka lama waktu menunggu untuk mendapatkan pekerjaan jika dikelompokkan berdasarkan program studi yang ada di Fakultas Ekonomi dapat dideskripsikan sebagai berikut: untuk prodi Pendidikan Ekonomi jumlah alumni dengan masa menunggu $1 \mathrm{~s} / \mathrm{d} 6$ bulan adalah sebanyak $38 \%$ jumlah, antara $7 \mathrm{~s} / \mathrm{d} 12$ bulan sebanyak $1 \%$ dan tidak membutuhkan waktu menunggu untuk mendapatkan pekerjaan adalah sebanyak $61 \%$.

\section{Profil Kesesuaian bidang pekerjaan menurut Program Studi}

Jikadideskripsikan kesesuaian
bidang pekerjaan alumni
berdasarkan bidang pekerjaan
menurut program studi maka
berdasarkan tabel 4.18 dapat
dideskripsikan sebagai berikut:
Untuk prodi Pendidikan Ekonomi


sebanyak $80 \%$ alumni sesuai bidang pekerjaannya dan sisanya $20 \%$ tidak sesuai.

\begin{tabular}{lc}
\hline KESESUAIAN & $\begin{array}{c}\text { PRODI PEND. } \\
\text { EKON }\end{array}$ \\
\hline SESUAI & 60 \\
\hline TIDAK SESUAI & 20 \\
\hline TOTAL & 80 \\
\hline
\end{tabular}

\section{Profil Persepsi Perusahaan Terhadap Kemampuan Alumni}

Indikator terakhir adalah persepsi perusahaan terhadap kemampuan alumni, dari tabel dibawah dapat dikatakan bahwa rata rata kemampuan alumni Fakultas Ekonomi UNJ menurut persepsi perusahaan pemberi kerja adalah baik, hal ini dibuktikan dengan prosentase secara keseluruhan dari item pertanyaan adalah sebanyak $12,5 \quad \%$ menyatakan kemampuan alumni sangat baik dan $75 \%$ kemampuan alumni dianggap baik serta $12,5 \%$ menyatakan kemampuan alumni kurang baik.Namun jika digambarkan lebih rinci berdasarkan masing-masing item pertanyaan, maka untuk kategori integritas alumni maka $20 \%$ persepsi perusahaan menyatakan sangat baik, dan $80 \%$ menyatakan baik. berdasarkan kategori etika dan moral maka $20 \%$ menyatakan sangat baik dan $80 \%$ menyatakan baik. berdasarkan kategori profesionalisme alumni maka $100 \%$ menyatakan baik. lalu berdasarkan penguasaan bahasa inggris maka 10 $\%$ menyatakan sangat baik, $60 \%$ perusahaan menyatakan baik dan
$30 \%$ menyatakan kurang baik. lalu berdasarkan penguasaan IT(Teknologi Informasi) maka 10\% perusahaan menyatakan sangat baik dan 80 persen menyatakan baik dan $10 \%$ menyatakan kurang baik. Ialu berdasarkan indikator kemampuan komunikasi maka $10 \%$ persen menyatakan alumni sangat baik dan $70 \%$ menyatakan baik lalu $20 \%$ menyatakan kurang baik.kemampuan kerjasama Tim $10 \%$ perusahaan menyatakan sangat baik, $80 \%$ menyatakan baik dan $10 \%$ menyatakan kurang baik. Terakhir berdasarkan kemampuan pengembangan diri alumni maka $10 \%$ menyatakan sangat baik dan $30 \%$ menyatakan baik sisanya $30 \%$ menyatakan kurang baik.

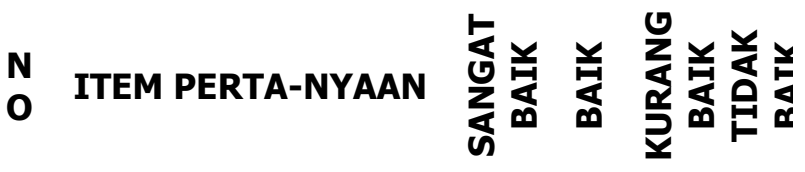

\begin{tabular}{lllll}
\hline 1 & $\begin{array}{l}\text { Bagaimanakah } \\
\text { integritas Alumni FE } \\
\text { UNJ }\end{array}$ & 2 & 8 & \\
\hline 2 & $\begin{array}{l}\text { Bagaimana Etika dan } \\
\text { Moral Alumni FE UNJ }\end{array}$ & 2 & 8 & \\
\hline 3 & $\begin{array}{l}\text { Bagaimana } \\
\text { Profesionalisme Alumni } \\
\text { FE UNJ }\end{array}$ & 10 & \\
\hline 4 & $\begin{array}{l}\text { Bagaimana } \\
\text { Penguasaan Bahasa } \\
\text { Inggris alumni FE UNJ }\end{array}$ & 1 & 6 & 3 \\
\hline 5 & $\begin{array}{l}\text { Bagaimana } \\
\text { Penguasaan IT alumni } \\
\text { FE UNJ }\end{array}$ & 1 & 8 & 1 \\
\hline & $\begin{array}{l}\text { Bagaimana } \\
\text { kemampuan } \\
\text { Komunikasi alumni FE } \\
\text { UNJ }\end{array}$ & 1 & 7 & 2 \\
\hline
\end{tabular}




\begin{tabular}{cccccc}
\hline 7 & $\begin{array}{l}\text { Bagaimana } \\
\text { kemampuan kerjasama } \\
\text { TIM alumni FE UNJ }\end{array}$ & 1 & 8 & 1 & \\
\hline $\begin{array}{l}\text { Bagaimana } \\
\text { kemampuan } \\
\text { pengembangan diri } \\
\text { alumni FE UNJ }\end{array}$ & 2 & 5 & 3 & \\
\hline Total & $\mathbf{1 0}$ & $\mathbf{1 0}$ & $\mathbf{1 0}$ & $\mathbf{0}$ \\
\hline
\end{tabular}

\section{Kesulitan Yang Dihadapi Alumni Dalam Bekerja}

Secara umum kesulitan yang dihadapi oleh alumni dapat diidentifikasikan dan dikategorikan sebagai berikut:

a. Kesulitan untuk beradaptasi dengan lingkungan kerja yang baru.

b. Kesulitan untuk berkomunikasi yang baik dengan rekan kerja dan atasan.

c. Kesulitan untuk mengoperasikan computer, terutama untuk aplikasi software terbaru.

d. Kesulitan untuk berkomunikasi dalam Bahasa Inggris, terutama pada saat wawancara kerja.

e. Kesulitan untuk membangun perilaku professional di tempat kerja.

f. Kesulitan berkaitan dengan perbedaan antara teori yang mereka terima dengan praktek di tempat kerja..

Berkaitan dengan kesulitan yang dihadapi oleh alumni pada saat mereka bekerja, pada penelitian ini, alumni juga diminta untuk memberikan saran, apa yang harus dilakukan oleh Fakultas Ekonomi untuk menjembatani kesulitan yang mereka alami, sehingga ke depan alumni yang lain tidak mengalami kesulitan pada hal yang sama. Dan dari jawaban responden ada beberapa point yang disarankan oleh mereka:

a. Mengembangkan materi-materi hard dan soft skill yang bisa menunjang pengembangan ketrampilan mahasiswa. Seperti Bahasa Inggris, komputer, komunikasi, kepribadian, dll.

b. Lebih banyak memberikan materi dalam bentuk praktek kerja yang sesuai dengan kebutuhan pasar saat ini.

c. Waktu Praktek Kerja Lapangan yang lebih lama.

d. Sering mengadakan kunjungan ke perusahaan, agar mahasiswa lebih mengenal dunia kerja.

e. Lebih banyak memberikan info lowongan kerja kepada alumni

f. Lebih meningkatkan matakuliah inti

g. Lebih ditingkatkan peran CDC sebagai agen pemberi lowongan kerja dan CDC memiliki hubungan ke banyak industri

\section{Persepsi Alumni Terhadap Layanan Kemahasiswaan}

Indikator berikutnya adalah persepsi alumni terhadap layanan bidang kemahasiswaan, dari data yang diperoleh dapat di deskripsikan bahwa 34,4 \% alumni menyatakan layanan kemahasiswaan baik, $50,8 \%$ alumni menyatakan layanan kemahasiswaan cukup baik dan 14,6 $\%$ menyatakan kurang baik. Jika dideskripisi lebih rinci tentang layanan keamahasiswaan yaitu layanan administrasi 
kemahasiswaan dinyatakan baik sebanyak $28 \%$ oleh alumni, dinyatakan cukup baik $44 \%$ dan dinyatakan kurang baik sebanyak $28 \%$. Untuk layanan beasiswa $32 \%$ alumni menyatakan baik, $59 \%$ alumni menyatakan beasiswa cukup baik dan $9 \%$ yang menyatakan kurang baik. Untuk kepuasan terhadap kegiatan ormawa $44 \%$ alumni menyatakan baik lalu $51 \%$ alumni menyatakan cukup baik dan $5 \%$ yang menyatakan kurang baik.

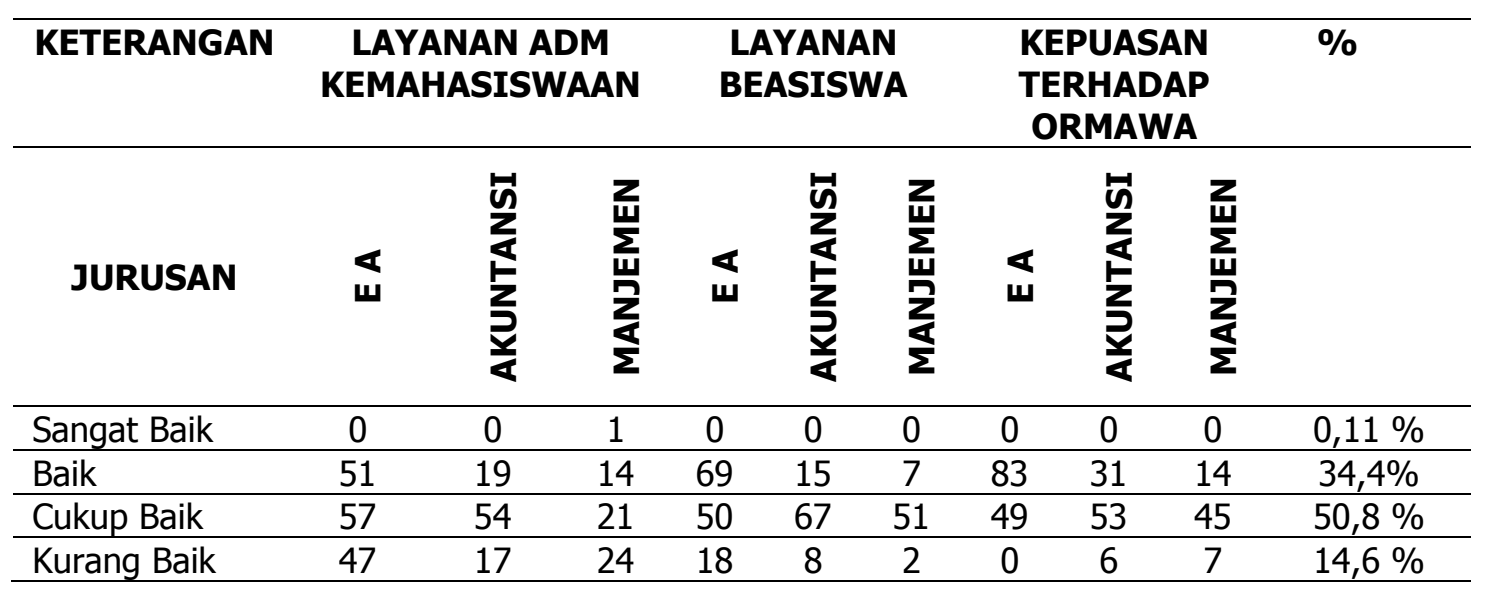

